\title{
The Rise of Online Learning and its Worthiness During COVID-19 Pandemic
}

\author{
Mustafa Kayyali
}

Azteca University, Mexico, North America

Corresponding author: kayyali@heranking.com

Received: $20-07-2020$

Revised: $25-10-2020$

Accepted: 28-11-2020

\begin{abstract}
Distance education appeared in some European and American universities in the era that preceded the emergence of the Internet (considering that the Internet as we know it today starts a new period of knowledge that is unlike any other period) in the 1970s when these HEIs were sending different educational materials via the mail for the student to study and analyze. These educational materials provided by those HEIs included books, notes, study plans, tapes, cassettes, audio, and video recordings, and all educational resources that can be transferred, sent, and used. In their turn, the students were instantaneously sending research seminars, courses, research, and studies by mail and in the same way used by HEIs. Meanwhile, the main obstacle for this educational system was that HEIs required that students must attend the mid-term and final exams at the university (distance education was not fully applied as we know it today, which allows the student to fully undergo the examination process via the internet). By the time, and after a few years, the development of satellite and visual broadcasting services, the pay-TV channels were providing e-services to students in the form of television broadcasting services and Pay Per View services. When the Internet appeared in the 1990s, the rapid development of the emergence of broadcasting, photography, e-lecturing, and communication technologies began. Direct contact with students and the invention of the e-mail by the American-Indian scientist Shiva Ayyadurai in 1978 had a great impact in facilitating the new methods of distance education. During the past few decades, distance education systems and curricula have proven that they can be a great, important, and influential companion to traditional education systems (and we will explain this later in this research). The biggest impact through which distance education system have shown that it is a logical, rational, healthy, safe and reliable option was during the current COVID-19 pandemic crisis, through which it appeared that distance education could be the only alternative solution (albeit temporarily) for the traditional education system during periods of epidemics and diseases that can affect the methodology and systems of work and life worldwide.
\end{abstract}

Keywords: Higher education Istitutes, HEIS, Distance education, Online education, e-learning, Epidemics, Diseases, COVID-19, Coronavirus, Universities, Virtual Reality, Augmented Reality, The future of higher education

How to cite this article: Kayyali, M. (2020). The Rise of Online Learning and its Worthiness During COVID-19 Pandemic. IJISC., 7(02): 63-84. 


\section{Objectives}

During the past few months, a lot of research, studies were discussing the feasibility that can be obtained through the application of distance education with the acceptance of some and the rejection of others to this new educational system. Some researchers were proposing possible alternatives through which the traditional methodology is replaced while rejecting distance education. This research aims to clarify the importance of distance education as a basic and influencing factor that can be relied upon during periods of epidemics, diseases, and unforeseen circumstances that can afflict humanity like the situation that humanity suffers nowadays as a result of the outbreak of the COVID-19 epidemic. This research also aims to clarify the role that distance education can play in protecting and building a healthy, and safe educational system.

\section{Introduction}

Global higher education is one of the main sectors that were affected by COVID-19 pandemic [90] [108] [7] [44]. However, today's challenges also present opportunities to increase online learning for higher education. Distance education can also help to encourage post-secondary students to pursue undergraduate studies. On March 11, 2020, the World Health Organization (WHO) officially declared COVID-19 a pandemic after assessing the global outbreak for several months [121]. The pandemic has caused the largest disruption to education systems in history, with nationwide closures forcing institutions to close temporarily and affecting 1.6 billion learners in more than 190 countries around the world [115]. It is estimated that the closure affected approximately $70 \%$ of all students worldwide [113] and the main challenge was to maintain continuity of learning while the threat of school closures was just around the corner. When we were looking for applied solutions, it seems that the simple and immediate solution is to conduct the study remotely using online resources [20], which was initially done in countries that suffered from severe virus outbreaks such as Italy, Spain, and South Korea, which switched to the distance education system to ensure safety and protection of its students.

\section{Historical Records}

Going back a few decades ago, the first steps for distance learning began in 1856 in Germany by Charles Toussaint, a French researcher who was teaching the French language in Berlin. The German musician Gustav Langenscheidt, who was a member of the Modern Languages Association In Berlin, was considering establishing a distance learning school [107], or as it was called at the time, a correspondence language school. After that, the USA began to establish correspondence curricula at Illinois State University in 1874, and with this step, distance learning spread around the world [89]. The first training courses began by correspondence at a later period by using parcels to reach students who could not attend their lectures according to the traditional campus education system [57]. In 1892, the University of Chicago established the first independent department for correspondence education and thus became the first university in the world to adopt distance education [39]. Distance education provided opportunities for adult students as it gave students a sense of responsibility towards their learning. Students would mail their assignments and jobs, then teachers would correct them and send them back grades with notes and feedback to students [58]. By the early twentieth century, communication technologies improved and distance education moved to radio waves after it was invented by the Italian Marconi in 1895 [122]. In 
1919 University of Wisconsin professors began designing an amateur radio station, the first wireless station licensed for educational broadcasting purposes [27]. In 1922, seventy-three other educational institutions obtained regular broadcast licenses, yet only half of those who obtained these licenses had broadcast stations, and by the end of the 1920s, 176 educational institutions had broadcast licenses [123]. Soon after, access to higher education was expanded again through the invention of television by the twentyfirst-year-old Philo Taylor Fransworth in 1927 [83], and this era became known as the era of audio-visual communication. The University of Iowa began experimenting with television for educational purposes in the 1930s [59]. In the 1950s, the US Federal Communications Commission (an independent agency of the United States government that regulates communications by radio, television, wire, satellite, and cable across the United States) began to reserve television frequencies for educational purposes and the value of television for education was enhanced [101] through the creation of American Public Broadcasting Company (an American non-profit company created in 1967 by the law of the United States Congress and funded by the American people, as mentioned under their banner used since 2000, to promote and help support public broadcasting) that has been working to encourage the growth and development of broadcasting Public radio and television, including an emphasis on the use of these media in teaching and for scientific and educational purposes.

In 1963, on the eve of Easter, British Howard Wilson established the University of the Air (a university without walls) and transferred the name to the Open University later, where radio and television were the main elements in the education process in addition to correspondence [30]. Thus, this type of distance education was announced, and the university was opened in 1969 and began offering its educational programs in 1971. Thousands of students in various fields registered hence [40]. Online learning appeared in the year 1983 [93] (this is because January 1, 1983, is the official start of the Internet. Before that, different computer networks did not have a standard way to communicate with each other. A new communication protocol called the Transport Control Protocol was created / Internet Action Protocol (TCP / IP).) When the Institute of Western Behavioral Sciences in the coastal La Jolla region of California opened the College of Management and Strategic Studies, it was using computers in the distance education process [79].

In 1989, the University of Phoenix began offering online educational programs [67]. In 1993 with the first appearance of the British designer Tim Burns-Lee internet browser, established by the University of Illinois, online learning began to flourish [98]. Starting in 1992, institutions of higher education began granting master's and doctoral degrees, and the first to start this step was George Washington University [3]. In 2000, the rate of enrollment of students around the world in educational courses via the Internet was $8 \%$, but this percentage increased to reach nearly $20 \%$ in 2008 [2].

The emergence of the Coronavirus crisis and its transmission to humans on October 6, 2019 [21] had a great impact on the emergence of distance education as one of the most effective, and best solutions and means to overcome repeated quarantine cases in many countries of the world. The pandemic has severely affected educational systems worldwide. Most governments have temporarily closed educational institutions, and many have switched to online education [23][24]. As of September 30, 2020, nearly 1.077 billion learners are currently affected by school closures in response to the epidemic, despite the inability to reach a specific number for the numbers of those affected due to the difficulty of determining closures and openings, in addition to determining the number of colleges, schools and universities that closed and open partially temporarily [104]. 
According to UNICEF, 53 countries are currently implementing nationwide closures, and 27 countries implementing local closures, affecting about 61.6 percent of students in the world [25]. In a study published in April 2020, it was shown that COVID-19 had affected 3278 higher education institutions around the world, including about 22 million students, and the virus caused $98 \%$ of these institutions to apply the online study system and prevented $95 \%$ of these institutions from teaching staff members of travel. $93 \%$ implemented the work of the administrative staff remotely, and $43 \%$ invested their resources in a way that contributes to developing the distance education system [16].

Returning to normal conditions, and comparing it to the exceptional situation imposed by the frightening spread of COVID-19 and the devastating consequences it has caused in all levels and areas of life, we find that distance education is a sound and logical healthy solution for societies and higher education institutions. COVID-19 showed this social and lifestyle solution clearly as one of the best applicable logical and rational solutions. Even if Corona did not appear, distance education would still exist and spread for a large number of reasons that encourage the emergence of this educational system, even if it will be less widespread than it is today due to the outbreak of the epidemic. What can be indicated is that we are grateful to distance education that it solved a real devastating dilemma for us that would have befallen educational institutions had it not existed before, and I firmly expect that the COVID-19 crisis would have invented distance education, even if it had not existed before [19].

\section{Historical hypothesis}

Let's go back in time to earlier periods. On this particular point, it appears to us the hypothesis and historical controversy represented in the following question: How did universities and higher education institutions teach educational curricula during the epidemics that previously afflicted humanity [34]? We know with certainty that mankind has always maintained its existence, durability and continuity despite all the deadly epidemics and has managed to survive, continue, recover and start again like the phoenix, and we know that throughout the medieval and contemporary history, the world witnessed the emergence of many deadly diseases and epidemics [92] that were either confined in specific countries, in specific geographical areas, or on specific continents, and they have caused the death of tens or even hundreds of millions [43] and caused demographic, social and economic changes throughout the world, and even pandemics that changed the course of history, such as the plague that spread in the third and fourteenth centuries [87], the plague of London that appeared in 1665 [111], smallpox that appeared in the fifteenth century in North and South America, the cholera epidemic that appeared in the nineteenth and twentieth centuries [60], yellow fever that appeared in the late nineteenth century [18] and influenza Spanish that appeared in 1918 [110] and also caused millions of deaths. We know that the history of mankind was a case of ups, downs and falls, progress and development in one hand, and regression and retreat on the other one[103]. What matters at this point is that question: As long as mankind suffered from the emergence of these epidemics and deadly diseases that changed the course of life and made it in some periods be face-to-face with the fear of annihilation and total extermination, how did higher education institutions manage to face the difficult conditions and overcome them? How were higher education institutions able in the centuries between the fifteenth and the beginning of the twentieth century to overcome viruses and epidemics and maintain the educational process [68]?

Simply, humanity, during its long history, has not been able to overcome the dilemma of continuing educational institutions to operate during epidemics and diseases, and what it simply was doing was 
postponing the problem without finding a solution. Simply, HEIs were stopped until the wave of the virus ended and after that, the educational institution begins again, with the remnants of its teaching staff (in case anyone left alive due to the great numbers of deaths caused by epidemics) [80] and continues the progress of educational process until the arrival of any problem, war, epidemic, or other deadly disease that leads to the cessation of academic life to turn the wheel on again and again! That was how academic life was going! Simply enough, the epidemic causes an intellectual psychological trauma that affects the entire society and leads everyone to think of a survival instinct [22][14][74][119][33]. Precisely at this moment, other considerations are thought of as secondary, and human safety and protection is the first priority that must be maintained, and supported [85].

During the 1918-1919 Spanish influenza pandemic in the United States [1], school closures and the ban on public gatherings were associated with lower overall death rates, like the cities that witnessed the highest rates of educational institution closures were the least affected by the influenza pandemic [72], and the closure took place for an average of 4 weeks. This was done in 43 American cities, and studies concluded that closure reduces the rate of pandemic influenza infections by $90 \%$ [48]. With the outbreak of the Coronavirus epidemic, a group of epidemiologists, virologist, and biologists supported the closure of schools, universities, educational institutions, and vocational education institutions in order to cut off the path of infection, slow the spread further, and buy time to research and produce a vaccine if this is possible [106]. After these researchers conducted a comparison between Covid on the one hand and the Spanish flu, on the other hand, they noticed that influenza cases decreased when schools, universities, educational institutions, and vocational education institutions were closed [15] and re-appeared when reopened, which directly indicates the need to close educational institutions during the emergence of epidemiology [61].

The safety and security factor is the first factor that was and is still seen in difficult times [100]. This is due to the survival instinct that can be justified at any time. As it is known, the great Babylonian flu epidemic that struck the regions of Babylon, central and southern Asia, and Mesopotamia in $1200 \mathrm{BC}$ caused the death of very large numbers of people at that time [41], while the Anthony epidemic that struck Europe in $250 \mathrm{AD}$ caused the death of more than 10 million people [70].As for the Justinian epidemic that struck Europe and Western Asia in $541 \mathrm{AD}$, it caused the death of about 50 million people [52][32], while the plague that struck Europe, Asia, and North Africa in 1346 caused about 200 million deaths, which was estimated About $60 \%$ of the continent's population [5], measles caused about 8 million deaths in Mexico alone in 1520 [4][102], while the plague of Egypt, which struck in 1609, caused a million deaths, and cholera that struck Russia in 1846 caused the death of about a million people [37], with a death rate similar to that of the flu that struck the world in 1890 [35].The largest number of deaths was of the Spanish flu that struck the world in 1918 and caused about 50 million people deaths, which was estimated at about $3 \%$ of the world's population [76]. Typhoid caused the death of 2.5 million people in Russia in 1918 [82][77]. The death rate for the Asian flu that struck the world in 1957 has reached 4 million infections [125][78][124].

\section{Logical Prospects}

These aforementioned figures show that humanity has suffered from dozens of deadly diseases and epidemics that have had a devastating impact on its path and development. All these diseases and epidemics led to a complete cessation of life, and this cessation was not limited to the functioning of 
higher education institutions alone, as we mentioned, complete closure was the only way to survive, as the options were very limited between complete closure and which means preserving life, and the lack of compliance with the closure, which will lead to an increase in cases and rates of death and fatalities. Throughout history, the University of Oxford responded in a period before the outbreak of the epidemic by sending the majority of its students and staff to the countryside away from the campus, and some secondary solutions were applied at that time, which had a partial role in maintaining students' implementation of part of the educational process. Among these secondary solutions, students were asked to do some assignments during the quarantine period and were required to continue carrying out academic operations while they were in their homes. All these procedures were aimed at maintaining a point of contact between the student on the one hand, and the educational process on the other hand. Everyone knew at the time that closing educational institutions is a difficult option for all parties and for all those who are related to the educational process, but it remains the best option compared to the increase in the spread of the epidemic and the difficulty of controlling it and the resulting high death rates [36]. In 1916, the US Bureau of Education declared that "School education is important, but life and health are more important" [65].

The closure was the only solution to escape death, and the educational process was the only loser from this closure. The repeated shutdowns caused the educational process to be subjected to very violent shocks, which led to the suspension of education for long periods and the loss of millions of students, and tens of thousands of years of their time. Let's go back in time to our present time and look at epidemics from today's perspective. Do we have a solution and an alternative that enables us to preserve the permanence and continuity of the educational process while preserving the safety and security of students? Do we have a solution by which we can keep students and their health? Do we have a solution that we can apply today in the face of Coronavirus, and we can also use it in the future in the event of similar viruses and epidemics? Can higher education institutions be kept in working order while maintaining the highest levels of safety and care for students and teachers [62]?

The answer to these questions is yes, and the solution lies in applying distance education during these difficult times [45]. This educational system is the best option that enables us to continue the educational process without gambling with the factor of safety and security [8]. The distance education system guarantees the continuation of the educational process during epidemics and pandemics that can afflict humanity [73]. It is an available and easy option that can be accessed from anywhere without any time restrictions [114].

\section{Logical Hypothesis}

If an alternative to traditional education exists, why should we refrain from implementing it? What are the other alternatives available to us, with the exception of stopping the educational process completely, or teaching through the traditional curriculum and bearing the disastrous and very high-risk rates and ratios that could result from such a decision? Is distance education considered a reasonable alternative to traditional education during epidemics and disasters that could afflict humanity?

The Ivy League universities are the most distinguished in the United States [126], such as Harvard University, Princeton University, Brown University, and Yale University. As some of the oldest and most respected universities in the country, Ivy League universities can easily influence trends in the higher education sector [75]. If online education proves to be good enough for Ivy League universities, 
it will probably be good enough for the rest of the universities in the world, and in this regard, these universities have begun to offer distance education programs (albeit cautiously) and some have also begun to introduce a hybrid education system (traditional education combined with distance education ), while some of these universities, such as the University of Pennsylvania, for example, have decided to provide some educational programs entirely through the Internet [63]. The most important American universities for 2020 also offer undergraduate programs via the Internet, and perhaps the most important of these universities are Arizona State University, Oregon State University, Florida University, Colorado State University, University of California Wilmington, University of Oklahoma, Colorado State University, Washington State University, and the University of Massachusetts Lowell, and Pace University. Other studies indicate that several important American universities offer graduate programs entirely through the Internet [127] and they are Johns Hopkins University, Northwestern University, University of California, Los Angeles, New York University, University of Texas, Austin, Georgia Tech, and University Boston, Ohio State University, University of Maryland, and University of Pittsburgh.

Students can obtain postgraduate degrees from the most prestigious accredited universities around the world [112] without risking community safety and without any risk. Based on that, is it not logical to adopt a distance educational system instead of risking lives?

\section{Distance education: The Best Choice for Difficult Circumstances. Benefits of Distance Education}

During the Coronavirus crisis, distance learning, or as it is called, online learning appeared as a safe, practical, easy and viable option for sustainability, development, and improvement despite all the difficult circumstances that resulted from the epidemic [118]. Besides, it is an easy-to-access option for the student, easy to implement for the educational institution, and easy-to-deal with faculty members. As we explained earlier, distance education spread greatly even before the outbreak of the Coronavirus epidemic, and it had a positive impact on all corners of the educational process and in many cases, it showed a great advantage over traditional education. Perhaps many view distance education with suspicion and doubt [84], given that one of the components of the real educational process is direct communication between the lecturer and the student, forgetting that modern communication technologies such as Zoom and Skype platforms have allowed direct and real-time communication between the lecturer and the student without feeling the presence of these obstacles cited by some theorists. Distance education is a reality and it is not a trend born as a result of circumstances that will disappear over timeor with the disappearance of the COVID-19 pandemic, it is very important to benefit from the experiences we have gained during this pandemic and to apply those experiences in the event of other epidemics emerging in the coming years [54].

In general, during difficult circumstances, the least harmful, safest, and best options can be considered for the components of the educational process of higher education institutions. Here, at this point specifically, we find ourselves in front of the conditions that humanity was suffering from about a hundred years ago, during the spread of the Spanish flu with the catastrophic repercussions That brought about. On this particular point, we find ourselves, thanks to distance education, in front of a very large advantage that did not exist before, and was not accessible in previous periods.

Here, we have the right to propose the following question: Why should we risk the health and safety of our students, their security, and their future by resorting to stopping the educational process, or risking 
their lives by forcing them to attend lectures in universities if an alternative to this risk is available and achieves the same results of the educational process? Why do those in charge of building the educational system refuse to rely on distance education for irrational reasons at a time when we are losing thousands of years of our priceless time? Is there a reasonable and safe alternative (other than distance education) that can be relied upon in the exceptional circumstances resulting from the Covid epidemic [71]? Were those in charge of the educational process able to build a new, sound, safe, and reliable system during the spread of epidemics, health, and environmental disasters, except for distance education?

To refute all the accusations against distance education, the following approaches can be presented:

- Safe Option: the application of distance education guarantees the safety and security of the members of the teaching process [81] and does not contradict the application of quarantine policies that countries take to reduce the escalation of infection rates, which ensures the safety of the students, and achieves the maximum possible benefit in a way that does not lead to stopping the educational process at all.

Fully interactive process[11]: Some assume that distance education prevents the existence of contact between the components of the educational process and that the quarantine cases imposed by Coronavirus cause the cancellation of direct communication between the teacher and students, and between students each other. Certainly, this is completely false, as direct communication exists in real terms [12] and even dates for lectures, educational sessions, question discussions, jobs, and other activities that take place directly and with the participation and interaction of all students, which ensures the highest possible degree of interaction [64]. Some lecturers require students to keep the cameras of their mobiles/laptops open, which would achieve optimal communication between all parties, ensure participation and access to information and also achieve the standard of transparency, credibility, and commitment in the educational process [86].

* Credibility and transparency of the exam process [50]: When applying the examination process, students are asked to keep the cameras of their mobile/laptop open, and they are also asked to shoot a video clip that proves that no one else is in the room with them, and their eye movements are even monitored if it is far away or not connected to the screen or the exam. Some universities also apply the open examination system, which is a system that allows more ease for the student and a higher level of creativity in providing the exam answer [88].

* Flexibility of the educational process: the information can be accessed at any time and place without any restrictions [49]. You can also watch the lectures that the teacher gave repeatedly. Furthermore, you can enter into immediate discussion rooms with colleagues in the same class, which ensures a high level of flexibility in the educational process and access to information. You can review your to-do list, chat with colleagues, and take beta-tests at any time. All this process only requires access to a stable, acceptable-speed Internet connection. In addition, the online examination system enables students to obtain their test scores upon completion of the exam, and those students do not have to wait to find out about theircommitted mistakes in the exam[91].

Student is the centre of the educational process[38]: One of the pillars of successful education is that the student is the focus of the educational process, which is something that educational institutions have had difficulty implementing during the spread of the Coronavirus pandemic because student safety is the most important consideration for these institutions. Emphasis on safety 
caused a restriction of focus on student's benefit and the information that could be obtained during the study [116]. Distance education guarantees the realization, support, and development of this pillar. When applying distance education, everything is devoted and centered to serve students. Those students can access all educational resources, attend all recorded lectures, do chats with their colleagues, send emails to their teachers to inquire about unintelligible points, and conduct experimental tests that contribute to increasing realizing the content of the educational process, the examination, and other important points that ensure that the student has access to all the resources that ensure the quality of the beneficiary, and in this case, the beneficiary is the student, the focus and pillar of this educational process [66].

* Access to information for life [117]: The distance education system enables students to have the flexibility to access information at any time [51], even after the completion of the educational process, which ensures easy verification of information, accessibility, and validation of any available idea. It also ensures a review of any idea put forward for discussion [99].

* Additional skills: Of course, we all strive to make the most of our time during the outbreak of the COVID-19 pandemic, and for this reason, when applying the distance education system, you will learn additional skills that can be applied and used later, such as internet search skills, communication skills, online shopping, and even getting a job via the Internet. It seems that we are facing an additional, real, highly effective, and useful skill that can be used at any time, and applied under any circumstances and get real benefit from it later.

Less expensive than traditional education: In some cases, distance education is less expensive than traditional education and in many cases, you can get the same program that you want to get in the traditional education system, but at a lower cost than traditional education. Distance education also saves costs for travel, transportation, reservations, hotels, and all other costs that can be saved when implementing the online education system [56].

Quality Assurance: Given the mechanism for programmatic accreditation, quality assurance agencies are currently accrediting educational programs following the distance education system, and special quality assurance bodies have been established concerned with the accreditation of online programs and online-based educational institutions. In addition to that, several academic networks have emerged that included educational institutions that provide educational programs according to the distance education system.

Saves time: Given the traditional situation (before the outbreak of the Covid epidemic), distance education can save a lot of time that you can spend on travel and transportation to attend lectures or even to wait for the lecture date. This time can be saved in the case of distance education [53].

- International and global context: The application of distance education provides the opportunity for the student to study any program in any country, and any university regardless of its location, or distance. With the outbreak of the Coronavirus pandemic, the emergence of great travel difficulties, and the difficult conditions set by some countries, distance education appears to be a great opportunity for students wishing to study in universities far from their home countries [69]. 


\section{Is Distance Education a Fair Opportunity For All? The Negatives of Distance Education}

Distance education cannot be viewed as a fair opportunity for all students everywhere, and the reason for this is the lack of adequate and appropriate resources for these students. When looking at the countries of the developed world, we find that more than $95 \%$ of their regions are equipped with the Internet and fast connection, while it seems tragic in other regions and countries such as India, where about $70 \%$ of Indians who live in rural areas are still unable to reach to digital technology [47], which makes the return of traditional education a very important issue in these areas. Besides, the social conditions resulting from the Covid pandemic, which have not yet allowed society to accept this new educational system, cannot be overlooked. Up to this point, some countries refuse to accept certificates obtained by students according to the distance education system. Moreover, the philosophy of distance education is still not sufficiently applied around the world, and much effort must be made to bridge this gap between society on the one hand, and the educational system based on distance education on the other hand.

We also find inequality and fairness in this educational system. On the one hand, distance education can be applied in theoretical colleges and colleges that rely on educational programs that do not depend on attendance, while this seems impossible in applied colleges that require the application of practical skills, and training in private hospitals or clinics, and thus, there will be a state of injustice when applying this educational methodology [9].

Some of these disadvantages can be illustrated as follows:

* The lack of acceptance of community for this educational system: The effects of the Coronavirus pandemic are still overwhelming on society, and many researchers still reject this option of applying distance education despite the absence of rational and logical alternatives. Many researchers claim that it is not feasible to implement the remote education system without trying to search for other options that can be offered to students and educational institutions. Of course, it is not logical and rational to repeat the 1918 influenza scenario to deal with education by stopping educational institutions. At the very least, we must search for a rational choice that can be relied on.

* Labor market VS online degrees: Up to this point, and despite the impact of the COVID-19 pandemic, the labor market still looks at the degrees issued by educational institutions that offer their programs according to the distance education system with suspicion, and doubt[42], and to view the graduate certificate as being not credible enough to compare with the degree issued according to the traditional education system. The labor market, exhausted and severely affected by the Covid pandemic, appears in front of a state of suspicion and doubt that will take a long time to be able to get rid of, and a longer time to be able to recover from the difficult phase it is going through nowadays. Students can overcome this dilemma by studying at reputable universities, which contributes to the overall acceptance of the student's degrees by employers [10].

* Governments VS online degrees: In some countries, especially in the third world countries, degrees issued by educational institutions that offer their programs according to the distance education system are rejected, without providing any rationale or logical reason, although these governments ask their local universities to apply distance education due to COVID-19. On this particular point, it appears that government agencies need to define clear, consistent, logical and rational standards that define the process for accepting and equating these degrees. 
The inability to apply this system in practical colleges: This problem is one of the most common problems referred to by those who reject the application of this educational system, as it is impossible to apply distance learning in the faculties of medicine, pharmacy, dentistry, anatomy, and surgery. It is also extremely difficult to apply distance learning in medical, nursing, physical therapy, and paramedics programs, in addition to many other programs that are impossible to implement according to the distance learning system. This logical and ethical dilemma represents a reason for which a solution must be found, and technological progress (such as adopting virtual and augmented reality technologies) can be relied upon to improve the study of these programs, even if temporarily at the current stage until other logical solutions are found, or to end the Coronavirus pandemic and its devastating impact on education.

Increases social isolation: Certainly, the educational process under the traditional educational system is considered a distinct and unique social process based on the interaction between all components of the process from students 'discussions with teachers, students' discussions with each other, research seminars, and participatory projects that students undertake each other [94]. When the distance education system is applied, this golden circle of communication fades and turns into an intangible communication process that takes place in front of the computer screen or the screen of the tablet device, a communication process that does not include the intimacy and emotion provided by the traditional education process. We know that this state covers all aspects of life according to the state of quarantine resulting from Coronavirus, but it increases and doubles during the application of the study process [17].

* The possibility of exposure to chronic diseases: If the academic program is long (in the case of studying a bachelor's or master's program), distance education can lead to the student's injury with chronic diseases, pain in the back, head, eyes, joints, and wrists, in addition to general stress, and these chronic diseases are the result of spending long times in front of a computer screen, or tablet screen, which would not have happened if the traditional educational system had been implemented.

* Poor time management: This educational system can lead to poor time management so that students can spend long hours on social media and social media without realizing any real tangible benefit [96]. This can happen as a result of a reaction to spending long hours during lectures. Thus, social media is an ulterior motive to escape from social isolation, but at the same time, it increases his isolation. Emphasis should be placed on time control and time management while dealing with this educational system [109].

Difficulties facing transparency policies: We have already mentioned that it is difficult (and not impossible) to implement transparency policies and to ensure the credibility of the examination process that students are subjected to while taking exams. The reason for this is that there are always ways and means by which to circumvent and deceive the standards and exam systems. When applying distance education, focus must be placed on information security, the security of the educational institution, and the security of the entire examination process, in a manner that preserves the credibility of the educational and examination system of the institution.

* Theory without application: Many educational institutions that offer educational programs according to the distance education system tend to pay attention to the theory and theoretical 
approaches of the educational process without showing sufficient interest in the practical application of these practical skills. Attention should be shown at a similar level to both theory and practice, which contributes to the development of the educational system as a whole, and not in the part that does not provide real benefit to the student.

\section{Distance Education During Epidemics: A True Haven for Tough Times}

As we have seen above, the distance education system cannot be viewed with suspicion and doubt, as it is an educational system that is truly established and applied by the most important international universities and provides educational programs for the bachelor's, master's, and doctoral stages. It offers recognition for its programs, in addition to joining academic networks for ensuring the quality of educational work. Looking back in time, we find that the educational process has stopped many times as a result of the spread of wars, epidemics, and diseases that have decimated humanity and led to the suspension of the educational process for many years waiting for the disease to end. Suppose in our day, that the coronavirus pandemic would stay for the next 5 or 10 years before finding a drug, or suppose, for example, that a new virus appeared and had a devastating impact greater than the impact caused by COVID-19 and led to the complete cessation of life and the imposition of a complete quarantine in a similar way to what is happening today. If the emergence of epidemics is frequent throughout ancient, modern, and contemporary history, should not a new educational system be formed that can adapt to the existence of these epidemics and provide the educational process, even if it is of a slightly lower level and standards than the traditional education system. Why should we repeat the same previous method of response that humanity has shown in dealing with epidemics (such as the Spanish flu epidemic) today despite the passage of more than a hundred years, and despite the existence of radically different solutions? Why do we put before our eyes two scenarios without even thinking about the third: Either we stop the entire educational process and impose quarantine and a complete ban on all educational activities and events, or we allow the opening of educational institutions and expose our lives and the lives of our students and academics to great risks, and side effects that could afflict their lives, or even cause them to contract epidemics and diseases and lead to death? Why don't we consider the third scenario, which guarantees the safety and security of all students on the one hand, and the educational process proceeding in an almost normal manner without prejudice to any of its components or even without affecting the quarantine cases imposed by governments to preserve their people and their safety on the other hand.

Should we not be characterized by some level of responsibility towards society and its safety and security, and at the same time ensuring the progress of the educational process? What will happen if COVID-19 continues throughout 2021? Will we have to close universities and educational institutions at that time? And if another epidemic emerges, what will we do then? Should life stop because some critics refuse to apply distance education? Distance education is the best, most applicable option, the least harmful and the least dangerous, and the most peaceful and secure for the university and students, and the most stable and sustainable.

\section{Recommendations and Suggestions}

Universities are advised to develop platforms and applications that contribute to supporting distance education, thus contributing to the further development and improvement of this educational system and to ensure that the defects it contains are eliminated. 
* We advise higher education institutions to develop specific systems that ensure that no tampering or fraud occurs in the examination processes, testing, and evaluation processes, in a way that contributes to enhancing the transparency of the entire educational process.

* We recommend universities to train the teaching staff so that they are fully and completely qualified to deal with students, and deal with these new technologies in a manner that ensures information is being understood by students.

* We ask the employers of the labor market to enact special policies that guarantee the credibility of the degrees obtained by students, and that those degrees are appropriate for the labor market. Employers of the labor market (on an international level) can establish an association that includes universities and educational programs (whether professional or academic) whose graduates can work for them and in their companies and institutions, and conclude a charter for the directors and heads of these companies and institutions pledging to accept the scientific, professional and academic qualifications that graduates from distance learning institutions can provide to obtaina job.

* We recommend developing academic networks in support of higher education similar to those of quality assurance bodies and agencies such as International Network for Quality Assurance Agencies in Higher Education INQAAHE [46], The European Association for Quality Assurance in Higher Education ENQA [28], Arab Organization for Quality Assurance in Education AROQA [6], Central and Eastern European Network of Quality Assurance Agencies in Higher Education CEENQA [13] and European University Association EUA [29]. These academic networks aim to develop a system that includes licensed and accredited recognition, and quality bodies that provide recognition services to universities that offer educational programs according to the distance education system.

* Developing private networks that include universities, educational institutions, and higher education institutions that provide distance education programs and enhance the work plan of these universities.

* We recommend that recognition and quality assurance agencies recognize programs that depend on distance education (except for some medical and applied programs) and create a special and specific system that guarantees the achievement of all basic standards to ensure the quality process for these programs.

* We advise governments, higher education councils, and ministries of higher education around the world to recognize the provided educational qualifications according to the distance education system. Governments and ministries can establish specific, consistent, and clear criteria that guarantee the credibility of universities offering these programs and the credibility of the educational programs offered.

We recommend supporting, developing, and investing in advanced visual technologies that will contribute to strengthening the e-learning industry [31][26][55]. These technologies include virtual reality (VR), Augmented Reality (AR), and technology that provides users with an experience aimed at excluding their actual physical environment [95][120]. At the same time, augmented reality adds digital elements to the live view of the process [97][105]. 
* Developing and presenting visual media to be presented to the community that clarifies the role of distance education in overcoming the effects and consequences of the Coronavirus pandemic and its role in addressing epidemics and similar diseases that may occur at a later stage.

Supporting, encouraging, and financing studies that clarify the future role of distance education

* Publishing and developing free educational platforms that can be used by students during the epidemic.

Developing applications that are concerned with information security and protection that can protect students' databases, lists, and exam records in a way that ensures that only those involved can access them.

\section{CONCLUSION}

Distance education is here to stay, and there is no prospect for it to stop, mutate, or change. We must accept this fact and adapt to it. After this educational system has proven that it is prepared to deal with epidemics and pandemics that afflict humanity, we expect that it will witness progressive progress in the coming years so that it becomes a direct match for traditional education even in the absence of epidemics and disasters.

\section{REFERENCES}

1. 1918 Pandemic (H1N1 virus). (2019, March 20). Retrieved December 15, 2020, from https://www.cdc. gov/flu/pandemic-resources/1918-pandemic-h1n1.html

2. 50 Online Education Statistics: 2020 Data on Higher Learning \&amp; Corporate Training. (n.d.). Retrieved December 15, 2020, from http://www.guide2research.com/research/online-education-statistics

3. A Select Chronology of George Washington University. (n.d.). Retrieved December 15, 2020, from https://library.gwu.edu/scrc/university-archives/gw-history/a-select-chronology-of-george-washingtonuniversity

4. Acuna-Soto, R., Stahle, D., Cleaveland, M., \&amp; Therrell, M. 2002. Megadrought and megadeath in 16th century Mexico. Retrieved December 15, 2020, from https:/www.ncbi.nlm.nih.gov/pmc/articles/ PMC2730237/

5. Alchon, S.A. 2003. A pest in the land new world epidemics in a global perspective. Albuquerque: University of New Mexico Press.

6. Arab Organization for Quality Assurance in Education. (n.d.). Retrieved December 15, 2020, from https://aroqa.org/en

7. Aristovnik, A., Keržič, D., Ravšelj, D., Tomaževič, N., \&amp; Umek, L. 2020. Impacts of the COVID-19 Pandemic on Life of Higher Education Students: A Global Perspective. https://doi.org/10.20944/ preprints202008.0246.v2

8. Armstrong-Mensah, E., Ramsey-White, K., Yankey, B., \&amp; Self-Brown, S. 2020. COVID-19 and Distance Learning: Effects on Georgia State University School of Public Health Students. Retrieved December 15, 2020, from https://www.frontiersin.org/articles/10.3389/fpubh.2020.576227/full 
9. Basantia, T.K. 2018. Implementing Practical Based Courses Under Open and Distance Learning System: A Study of The Perception of Learners and Counsellors. Turkish Online Journal of Distance Education, 19(2): 201-214.

10. Castaño-Muñoz, J., Carnoy, M. and Duart, J.M. 2016. Estimating the economic payoff to virtual university education: a case study of the Open University of Catalonia. High Educ., 72: 1-24.

11. Cavanaugh, C. 1999. The Effectiveness of Interactive Distance Education Technologies in K-12 Learning: A Meta-Analysis. Retrieved December 15, 2020, from https://eric.ed.gov/?id=ED430547

12. Cavanaugh, C. 2001. The effectiveness of interactive distance education technologies in K-12 learning: A meta-analysis. International Journal of Educational Telecommunications, 7: 73-88.

13. Central and Eastern European Network of Quality Assurance Agencies in Higher Education CEENQA. (n.d.). Retrieved December 15, 2020, from https://www.ceenqa.org/

14. Chen, B., Li, Qx., Zhang, H. et al. 2020. The psychological impact of COVID-19 outbreak on medical staff and the general public. Curr. Psychol. https://doi.org/10.1007/s12144-020-01109-0

15. Closing schools won't stop pandemics: Study. (2009, July 20). Retrieved December 15, 2020, from https://www.reuters.com/article/us-flu-schools-idUSTRE56J4OO20090720

16. Crist, M. (n.d.). Online courses challenge students and faculty - but they may offer more effective learning environment if you can adapt. Retrieved December 15, 2020, from https://pnwpioneer.com/5421/ campus/online-courses-challenge-students-and-faculty-but-they-may-offer-more-effective-learningenvironment-if-you-can-adapt/

17. Croft, N., Dalton, A., \&amp; Grant, M. 2010. Overcoming Isolation in Distance Learning: Building a Learning Community through Time and Space. J. Edu. Built Environ., 5(1): 27-64.

18. Cunha, B.A. 2004. Influenza: Historical aspects of epidemics and pandemics. Infectious Disease Clinics of North America, 18(1): 141-155.

19. Dhawan, S. 2020. Online Learning: A Panacea in the Time of COVID-19 Crisis. Journal of Educational Technology Systems, 49(1): 5-22.

20. Distance learning solutions. (2020, July 07). Retrieved December 15, 2020, from https://en.unesco.org/ covid19/educationresponse/solutions

21. Dorp, L.V., Acman, M., Richard, D., Shaw, L.P., Ford, C.E., Ormond, L., . . Balloux, F. 2020. Emergence of genomic diversity and recurrent mutations in SARS-CoV-2. Infection, Genetics and Evolution, 83: 104351.

22. Dubey, S., Biswas, P., Ghosh, R., Chatterjee, S., Dubey, M. J., Chatterjee, S., . . Lavie, C.J. 2020. Psychosocial impact of COVID-19. Diabetes \&amp; Metabolic Syndrome: Clinical Research \& amp; Reviews, 14(5): 779-788.

23. Education Response to COVID-19 in the Caribbean. (2020, September 10). Retrieved December 15, 2020, from https://en.unesco.org/caribbean-education-response

24. Education: From disruption to recovery. (2020, September 08). Retrieved December 15, 2020, from https://en.unesco.org/covid19/educationresponse 
25. Education: From disruption to recovery, 2020, from https://en.unesco.org/covid19/educationresponse

26. Elmqaddem, N. 2019. Augmented Reality and Virtual Reality in Education. Myth or Reality? Int. J. Emer. Tech. Learn., (iJET), 14(03), 234.

27. Engel, H.A. 1936. WHA, Wisconsin's pioneer. Unpublished manuscript. Madison, WI: Wisconsin State Historical Society.

28. European Association for Quality Assurance in Higher Education (ENQA). (n.d.). Retrieved December 15, 2020, from https://enqa.eu/

29. European University Association (EUA). (n.d.). Retrieved December 15, 2020, from https://eua.eu/

30. Exhibition: Harold Wilson and The OU. (n.d.). Retrieved December 15, 2020, from https://www.open. ac.uk/library/digital-archive/exhibition/74/theme/2/page/2

31. Fernandez, M. 2017. Augmented-Virtual Reality: How to improve education systems. Higher Learning Research Communications, 7(1): 1.

32. Frerichs, R. (n.d.). An Empire's Epidemic - Scientists Use DNA in Search for Answers to $6^{\text {th }}$ Century Plague. Retrieved December 15, 2020, from https://www.ph.ucla.edu/epi/bioter/anempiresepidemic.html

33. Galea, S., Merchant, R.M. and Lurie, N. 2020. The Mental Health Consequences of COVID-19 and Physical Distancing: The Need for Prevention and Early Intervention. JAMA Intern. Med., 180(6): $817-818$.

34. Gordon, J., Weiner, E., McNew, R. and Trangenstein, P. 2010. Teaching during a pandemic event: are universities prepared?. Stu. Healt. Tech. Inform., 160(Pt 1): 620-624.

35. Great Britain. Local Government Board. 1893. Further report and papers on epidemic influenza, 1889-92: With an introduction by the Medical Officer of the Local Government Board. Presented to both Houses of Parliament by Command of Her Majesty. London: Her Majesty’s Stationery Office.

36. Harris, D. 2020. When Should Schools Reopen Fully in-Person? Challenges and Suggestions For School Leaders. Retrieved December 15, 2020, from https:/www.brookings.edu/blog/brown-centerchalkboard/2020/09/29/when-should-schools-reopen-fully-in-person/

37. Hays, J.N. 2006. Epidemics and Pandemics: Their Impacts on Human History. Santa Barbara, CA: ABC-CLIO.

38. Hisham, D.Z.A.K.I.R.A. and Rozhan Mohammed, I.D.R.U.S. 2003. Teacher- Learner Interactions in Distance Education: A Case of Two Malaysian Universities, Turkish Online J. Dis. Edu., (TOJDE), 4(3).

39. History of Distance Education Prof. Dr.Uğur Demiray Anadolu Üniversitesi İletişim Fakültesi Doç. Dr.Aytekin İşman Sakarya Üniversitesi Eğitim Fakültesi, DEMİRAY, U., \&amp; İŞMAN, A. (2014, March 17). History of Distance Education. Retrieved December 15, 2020, from https://dergipark.org. tr/en/pub/sakaefd/issue/11223/134000

40. History of the Open University. (n.d.). Retrieved December 15, 2020, from http://www.openuniversity. edu/why-the-ou/quality/history. 
41. History.com Editors. 2019. Pandemics That Changed History. Retrieved December 15, 2020, from https://www.history.com/topics/middle-ages/pandemics-timeline

42. Hugh Lauder and Mayhew, K. 2020. Higher education and the labour market: an introduction, Oxford Review of Education, 46(1): 1-9.

43. Huremović, D. 2019. Brief History of Pandemics (Pandemics Throughout History). Psychiatry of Pandemics, pp. 7-35.

44. Husain, N. 2020. (PDF) Impact of COVID-19 on Higher Education: Challenges, Opportunities and Road Ahead. Retrieved December 15, 2020, from https:/www.researchgate.net/publication/341203464_ Impact_of_COVID-19_on_Higher_Education_Challenges_Opportunities_and_Road_Ahead

45. Ince, E.Y., Kabul, A. \&amp; Diler, I. 2020. Distance Education in Higher Education in the COVID-19 Pandemic Process: A Case of Isparta Applied Sciences University. Int. J. Tech. Edu. Sci., 4(4): 343-351.

46. International Network for Quality Assurance Agencies in Higher Education. (n.d.). Retrieved December 15, 2020, from https://www.inqaahe.org/

47. Internet usage in rural India overtakes urban areas. (n.d.). Retrieved November 16, 2020, from https:// www.warc.com/newsandopinion/news/internet-usage-in-rural-india-overtakes-urban-areas/43588

48. Jackson, C., Mangtani, P., Hawker, J., Olowokure, B., \&amp; Vynnycky, E. 2014. The Effects of School Closures on Influenza Outbreaks and Pandemics: Systematic Review of Simulation Studies. PLOS ONE, 9(5).

49. Jingjing Zhang, Burgos, D. and Dawson, S. 2019. Advancing open, flexible and distance learning through learning analytics, Dis. Edu., 40(3): 303-308.

50. Jonsson, A. 2010. The use of transparency in the 'Interactive examination' for student teachers. Assessment in Education: Principles, Policy \&amp; Practice, 17(2): 183-197.

51. Judy Block, \&amp; Eastern Michigan University. (n.d.). Distance Education and the Digital Divide: An Academic Perspective. Retrieved December 15, 2020, from https://www.westga.edu/ distance/ojdla/ spring131/block131.html

52. Justinian's Flea - the plague of Justinian. (n.d.). Retrieved December 15, 2020, from http://www. justiniansflea.com/events.htm

53. Kagai, D. 2020. How Online Education Saves You Time and Money - Online Courses Attract Lower Fees Compared to on-campus Programs. Retrieved December 15, 2020, from https://www.constructionkenya. com/7763/online-education-saves-money

54. Kappel, H., Lehmann, B. \&amp; Loeper, J. 2002. Distance Education at Conventional Universities in Germany. Int. Rev. Res. Open and Distributed Learn., 2(2).

55. Kencevski, K. and Zhang, Y. 2019. VR and AR for Future Education. In: Zhang Y., Cristol D. (eds) Handbook of Mobile Teaching and Learning. Springer, Singapore.

56. Kendall Job, \&amp; Editorial Intern. (n.d.). University of Illinois Illinois Online University of Illinois at Urbana-Champaign. Retrieved December 15, 2020, from https://online.illinois.edu/articles/onlinelearning/item/2019/10/22/5-benefits-of-online-courses-vs.-a-traditional-classroom 
57. Kentnor, H. 2015. "Distance education and the evolution of online learning in the United States". Curriculum and Teaching Dialogue, 17: 21-34.

58. Kentnor, H. 2015. "Evolution of online learning in the United States". Curriculum and Teaching Dialogue.

59. Kettler, H., \&amp; Tade, C. 2012. University Libraries: The University of Iowa - The UI's distance learning future that never was. Retrieved December 15, 2020, from https://blog.lib.uiowa.edu/ studio/2012/05/

60. Korin Miller Updated March 10, \&amp; Miller, K. (n.d.). 6 of the Worst Pandemics in History. Retrieved November 16, 2020, from https:/www.health.com/condition/infectious-diseases/worst-pandemics-inhistory

61. Lewis, C.B. 1944. Shall the schools be open or closed during an epidemic of contagious disease?. J. School Healt., 14: 161-167.

62. Lily, A.E., Ismail, A.F., Abunasser, F.M., \&amp; Alqahtani, R.H. 2020. Distance education as a response to pandemics: Coronavirus and Arab culture. Tech. Soc., 63: 101317.

63. Lindsay McKenzie. (n.d.). Inside Higher Ed - An Elite Online Bachelor's Degree. Retrieved December 15, 2020, from https://www.insidehighered.com/digital-learning/article/2018/09/19/penn-introducesnew-online-bachelors-degree-program

64. Maboe, K. A. 2017. Use of online interactive tools in an open distance learning context: Health studies students' perspective. Health SA Gesondheid, 22: 221-227.

65. Mary Battenfeld | July 30, 2. (n.d.). What we can learn from how schools responded to the 1918 pandemic? How schools handled the disruption caused by the 1918 pandemic offers 3 lessons that are worth heeding today. Retrieved December 15, 2020, from https://www.greatschools.org/gk/articles/ what-we-can-learn-from-how-schools-responded-to-the-1918-pandemic

66. Maxwell, L. 1995. Integrating Open Learning and Distance Education. Educ. Tech., 35(6): 43-48.

67. Miller, Gary; Benke, Meg; Chaloux, Bruce; Ragan, Lawrence C.; Schroeder, Raymond; Smutz, Wayne; Swan, Karen (2004). Leading the e-learning transformation of higher education.

68. Mishra, L., Gupta, T., \&amp; Shree, A. 2020. Online teaching-learning in higher education during lockdown period of COVID-19 pandemic. Int. J. Educational Res. Open, 100012. https://doi. org/10.1016/j.ijedro.2020.100012

69. Moore, M.G. 1996. International Distance Education: A Vision For Higher Education: Pre-conference Papers From the First International Distance Education Conference, the Pennsylvania State University, June 2-5, 1994. University Park, PA, PA: American Center for the Study of Distance Education, Pennsylvania State University.

70. Murphy, V. 2005. Health | Past pandemics that ravaged Europe. Retrieved December 15, 2020, from http://news.bbc.co.uk/2/hi/health/4381924.stm

71. Nair, T. (n.d.). 10 Reasons Why You Should Choose A Distance Learning Degree. Retrieved December 15, 2020, from https://www.indiaeducation.net/alternative-education/distanceeducation/10-reasonswhy-you-should-choose-a-distance-learning-degree.html 
72. Nina Strochlic and Riley D. Champine. 2020. How some cities 'flattened the curve' during the 1918 flu pandemic. Retrieved December 15, 2020, from https://www.nationalgeographic.com/history/2020/03/ how-cities-flattened-curve-1918-spanish-flu-pandemic-coronavirus

73. OECD Policy Responses to Coronavirus (COVID-19). (2020, September 24). Strengthening online learning when schools are closed: The role of families and teachers in supporting students during the COVID-19 crisis. Retrieved December 15, 2020, from http://www.oecd.org/coronavirus/policyresponses/strengthening-online-learning-when-schools-are-closed-the-role-of-families-and-teachersin-supporting-students-during-the-covid-19-crisis-c4ecba6c

74. Otu, A., Charles, C.H. and Yaya, S. 2020. Mental health and psychosocial well-being during the COVID-19 pandemic: the invisible elephant in the room. Int. J. Ment. Health Syst., 14(38).

75. Parker, T. 2020. The Value Of An Ivy League Education. Retrieved December 15, 2020, from https:// www.investopedia.com/financial-edge/0811/the-value-of-an-ivy-league-education.aspx

76. Patterson, K.D. and Pyle, G.F. 1991. The geography and mortality of the 1918 influenza pandemic. Bull Hist. Med., 65(1): 4-21.

77. Patterson, K.D. 1993. Typhus and its control in Russia, 1870-1940. Medical History, 37(4): 361-381.

78. Paul, W.E. 2008. Fundamental Immunology. Philadelphia: Wolters Kluwer/Lippincott Williams \&amp; Wilkins.

79. Paulsen, M.F., Holmberg, C., \&amp; Nipper, S. 2003. Online Education: Learning Management Systems: Global E-learning in a Scandinavian Perspective. Bekkestua: NKI.

80. Person, \&amp; Wilke, M. 2017. The 10 deadliest epidemics throughout history. Retrieved December 15, 2020, from https://www.news24.com/health24/medical/infectious-diseases/news/the-10-deadliestepidemics-throughout-history-20170928

81. Person. 2020. Learning from home: Distance education is the only safe choice. Retrieved December 15, 2020, from https:/www.theage.com.au/national/learning-from-home-distance-education-is-theonly-safe-choice-20200416-h1ne9j.html

82. Peter Spreeuwenberg, Kroneman, M. and Paget, J. 20198. Reassessing the Global Mortality Burden of the 1918 Influenza Pandemic, American J. Epidemiology, 187(12): 2561-2567.

83. Philo Farnsworth - Electronic Television - Computing and Telecommunications. (n.d.). Retrieved December 15, 2020, from https://lemelson.mit.edu/resources/philo-farnsworth

84. Powell, R. and Keen, C. 2006. The Axiomatic Trap: Stultifying Myths in Distance Education. Higher Edu., 52(2): 283-301.

85. Public health preparedness capabilities: National standards for state and local planning, March 2011. (2011). Atlanta, GA: Centers for Disease Control and Prevention, Office of Public Health Preparedness and Response.

86. Purcell-Robertson, R.M. \&amp; Sr., D.F. 2000. Interactive Distance Learning. Dis. Learn. Tech., pp. $16-21$. 
87. Qiu, W., Rutherford, S., Mao, A., \&amp; Chu, C. 2017. The Pandemic and its Impacts. Health, Culture and Society, 9: 1-11.

88. Radboud University - Radboud Teaching and Learning Centre. (n.d.). Effectiveness, Transparency and Feasibility - As well as being valid and reliable, an assessment must also be effective, transparent and feasible. Retrieved December 15, 2020, from https://www.ru.nl/lecturers/education/assessment-appraisal/ quality-demands/effectiveness-transparency-feasibility/

89. Rahm, D., \&amp; Reed, B.J. 1997. Going Remote: The Use of Distance Learning, the World Wide Web, and the Internet in Graduate Programs of Public Affairs and Administration. Public Productivity \&amp; Management Review, 20(4): 459.

90. Rashid, S., \&amp; Yadav, S.S. 2020. Impact of Covid-19 Pandemic on Higher Education and Research. Indian Journal of Human Development, 14(2): 340-343.

91. Roberts, T. 2006. From Distance Education to Flexible Learning. Central Queensland University, https:// www.researchgate.net/publication/234602127_From_Distance_Education_to_Flexible_Learning

92. Roos, D. 2020. How 5 of History's Worst Pandemics Finally Ended. Retrieved November 16, 2020, from https://www.history.com/news/pandemics-end-plague-cholera-black-death-smallpox

93. Rowan, R. 1983. Executive Ed. at Computer U. Fortune, March 7, 1983; Feenberg, Andrew (1993). "Building a Global Network: The WBSI Experience," in L. Harasim, ed., Global Networks: Computerizing the International Community, MIT Press.

94. Rush, P. 2018. Isolation and Connection: The Experience of Distance Education. Distances Et Médiations Des Savoirs, 23.

95. Scavarelli, A., Arya, A. and Teather, R.J. 2020. Virtual reality and augmented reality in social learning spaces: a literature review. Virtual Reality. https://doi.org/10.1007/s10055-020-00444-8

96. Sellers, E. 2016. Poor Time Management in Online Learning. Retrieved December 15, 2020, from https://education.seattlepi.com/poor-time-management-online-learning-1435.html

97. Shenoy, R. (n.d.). VR, AR and AI will Transform Universities. Here's How. Retrieved December 15, 2020, from https://unbound.upcea.edu/online-2/online-education/vr-ar-and-ai-will-transformuniversities-heres-how/

98. Sir Tim Berners-Lee invented the World Wide Web in 1989. (n.d.). Retrieved December 15, 2020, from https://www.w3.org/People/Berners-Lee/

99. Ståle Angen Rye and Zubaidah, I. 2008. Distance education and the complexity of accessing the Internets, Open Learning: The Journal of Open, Distance and e-Learning, 23(2): 95-102.

100. Staying safe outside during COVID-19. (2020, September 02). Retrieved December 15, 2020, from https://www.unicef.org/coronavirus/staying-safe-outside-during-covid-19

101. Steetle, R. 1959. The Changing Status of Educational Television. Journal of Educational Sociology, 32(9): 427.

102. Stevenson, S., Overpeck, J., Fasullo, J., Coats, S., Parsons, L., Otto-Bliesner, B., . . . Cole, J. 2018. Climate Variability, Volcanic Forcing, and Last Millennium Hydroclimate Extremes. Retrieved December 
15, 2020, from https://journals.ametsoc.org/view/journals/clim/31/11/jcli-d-17-0407.1.xml?tab_ body=fulltext-display- https://doi.org/10.1175/JCLI-D-17-0407.1

103. Strauss, L. 1952. On Collingwood's Philosophy of History. The Review of Metaphysics, 5(4): 559-586.

104. Study in Morbidity and Mortality Weekly Report describes a COVID-19 outbreak in the Hopi Tribe in Arizona. (2020, December 09). Retrieved December 15, 2020, from https://www.renforts7.fr/hotelemma-btb/index-education-covid-c26a6f

105. Sullivan, K., About Kathy Sullivan Kathy is an Instructional Technology Consultant on the CTL Team in Central Support at DePaul since July 2018. Before that she worked in Classroom Technology starting in 2012, Sullivan, A., Kathy is an Instructional Technology Consultant on the CTL Team in Central Support at DePaul since July 2018. Before that she worked in Classroom Technology starting in 2012, View all posts by Kathy Sullivan $\rightarrow$, \&amp; Says:, G. (2019, December 05). Instructional Design Tips, Advice, \&amp; Trends for Online \&amp; Distance Learning: Educational Technology and Online Course Design Help. Retrieved December 15, 2020, from https://www.iddblog.org/virtual-andaugmented-reality-in-education/

106. Swine flu: Schools should close to halt spread of virus, ministers told. (2009, July 21). Retrieved December 15, 2020, from https://www.telegraph.co.uk/news/health/swine-flu/5874683/Swine-fluschools-should-close-to-halt-spread-of-virus-ministers-told.html

107. The Evolution of the Character and Practice of Distance Education Börje Holmberg in: Open Learning, June 1995, pg. 47-53

108. The impact of COVID-19 on higher education: A study of interaction among students' mental health, attitudes toward online learning, study skills, and changes in students' life - https://www.researchgate. net/publication/341599684_The_impact_of_COVID-19_on_higher_education_A_study_of_interaction_ among_students\%27_mental_health_attitudes_toward_online_learning_study_skills_and_changes_in_ students $\% 27$ life

109. Todorov, G. 2018. The Importance Of Time Management In Online Learning. Retrieved December 15, 2020, from https://elearningindustry.com/time-management-in-online-learning-importance

110. Tognotti, E. 2009. Influenza pandemics: A historical retrospect. The Journal of Infection in Developing Countries, 3(05).

111. Top 10 Pandemics in Human History. (2020, August 04). Retrieved November 16, 2020, from https:// www.humainpodcast.com/top-10-pandemics-in-human-history

112. Top 25 Schools for Online Master's Programs: BestCollegeReviews. (2020, December 10). Retrieved December 15, 2020, from https://www.bestcollegereviews.org/top/online-masters-degree-programs/

113. UN Secretary General's Policy Brief: Education during COVID-19 and beyond launched. (2020, September 02). Retrieved December 15, 2020, from https://en.unesco.org/news/secretary-generalspolicy-brief-education-during-covid-19-and-beyond-launched

114. UNESCO. (2020). Distance learning strategies in response to COVID-19 school closures. Retrieved December 15, 2020, from https://unesdoc.unesco.org/ark:/48223/pf0000373305?posInSet=2 
115. UNSDG | Policy Brief: Education during COVID-19 and beyond. (n.d.). Retrieved December 15, 2020, from https://unsdg.un.org/resources/policy-brief-education-during-covid-19-and-beyond

116. Valcke, M. and Thorpe, M. 1995. Distance Education: A Particular Context for Teaching and Learning. Introduction to this Special Issue. European J. Psy. Edu., 10(2): 111-119.

117. Vicari, R. and Silveira, R.A. 2004. Distance Education and Lifelong Learning. In: Van Weert T.J., Kendall M. (eds) Lifelong Learning in the Digital Age. IFIP The International Federation for Information Processing, vol 137. Springer, Boston, MA. https://doi.org/10.1007/1-4020-7843-9_7

118. Vimbi P.M. 2018. ( $4^{\text {th }}$ ed.). The Good, the Bad, and the Ugly of Distance Learning in Higher Education, Trends in E-learning, Mahmut Sinecen, IntechOpen, DOI: 10.5772/intechopen.75702. Available from: https://www.intechopen.com/books/trends-in-e-learning/the-good-the-bad-and-the-ugly-of-distancelearning-in-higher-education

119. Wang, H., Xia, Q., Xiong, Z., Li, Z., Xiang, W., Yuan, Y., . . Li, Z. 2020. The psychological distress and coping styles in the early stages of the 2019 coronavirus disease (COVID-19) epidemic in the general mainland Chinese population: A web-based survey. Plos One, 15(5). https://doi.org/10.1371/ journal.pone. 0233410

120. Wesley, S. 2018. Augmented and Virtual Reality: The Future of Learning Experiences. Retrieved December 15, 2020, from https://virtualspeech.com/blog/augmented-virtual-reality-future-of-learningexperience

121. WHO Director-General's opening remarks at the media briefing on COVID-19 - 11 March 2020. (n.d.). Retrieved December 15, 2020, from https:/www.who.int/director-general/speeches/detail/who-directorgeneral-s-opening-remarks-at-the-media-briefing-on-covid-19---11-march-2020

122. Who Invented Radio: Guglielmo Marconi or Aleksandr Popov? (n.d.). Retrieved December 15, 2020 , from https://spectrum.ieee.org/tech-history/dawn-of-electronics/who-invented-radio-guglielmo-marconior-aleksandr-popov

123. Wood, D.N. and Wylie, D.G. 1977. Educational telecommunications. Belmont, CA: Wadsworth Publishing Company.

124. World Health Organization. 1970. Implementation of the International Health Regulations (2005): Report of the Review Committee on the Functioning of the International Health Regulations (2005) in relation to Pandemic (H1N1) 2009: Report by the Director-General. Retrieved December 15, 2020, from https://apps.who.int/iris/handle/10665/3350

125. World Health Organization. 2019. Pandemic Influenza Risk Management - A WHO guide to inform \&amp; harmonize national \&amp; international pandemic preparedness and response. Retrieved December 15, 2020, from https://www.who.int/influenza/preparedness/pandemic/influenza_risk_management/en/

126. Writers, S. 2020. What Is the Ivy League?: BestColleges. Retrieved December 15, 2020, from https:// www.bestcolleges.com/blog/what-is-ivy-league/

127. Writers, S. 2020. Best Online Master's Degrees \&amp; Program Guide of 2020: BestColleges. Retrieved December 15, 2020, from https://www.bestcolleges.com/features/online-masters-degree/ 